\title{
Chemical Laboratory Testing
}

National Cancer Institute

\section{Source}

National Cancer Institute. Chemical Laboratory Testing. NCI Thesaurus. Code C113078.

Testing of specimens or materials for various chemical properties. 